\title{
Superiority of Man and the Danger on Natural Resources: Linkage between Human Activities and the Death of Natural Resources in Kenya
}

\author{
George Ouma Ochola* \\ Department of Agronomy and Environmental Studies, Kenya
}

Submission: November 27, 2018; Published: December 20, 2018

*Corresponding author: George Ouma Ochola, Department of Agronomy and Environmental Studies, Kenya

\section{Abstract}

There are various explanations which try to clarify the position occupied by man as an organism on the earth's surface. Some scientific explanations have asserted that man evolved from primate beings and became a superior being overtime. On the other hand, the Biblical explanation provides the work done by the Supernatural Being in creating man on the sixth day and giving him dominion over all the birds of the air and other creatures on the earth's surface and in the see (Genesis 1:28). According to this verse, God Himself blessed man and gave him power to increase in number, fill the earth and to subdue it. This did not stop there, man was given power to rule over other creatures such as fish in the sea, birds among other living creatures that move on the ground. This is what is provided by the Judeo-Christian Ethic. The dominion that was given to man has not been utilized appropriately. Many resources have been degraded and some species have been lost. The power to increase, fill and subdue the earth has not been sustainable. Man has considered himself so superior that other organisms are now threatened with extinction. Rivers, streams, lakes, wetlands, forest ecosystems are now becoming endangered. Ironically, as man fails to consider these resources, he also endangers himself. This study was exploratory and used survey and document analysis to gather information. The findings of this study have revealed that the modern man digs his own grave by considering himself to be so superior and failing to take concern over other resources. The study therefore advocates for change of attitude among individuals for sustainable use of the available natural resources.

Keywords: Human superiority; Natural resources; Linkage; Danger kenya

\section{Introduction}

Man's ability to manipulate, modify and transform the earth is increasingly becoming a global issue of concern. It has been difficult to realize that however much superior we are, our lives depend on the natural resources within our reach. Man's developmental activities create more harm to the environment and endanger the natural resources available. He has misinterpreted and missed used the dominion he was given over other creatures. As was mentioned earlier, the power that was given to man was not that he destroys the resources but it was to be steward of these other resources. Misinterpretation of the power bestowed on man by God has been disastrous to other living organisms. The emergence of industries and locomotives that support man's life has been seen to impact on the environment negatively [1]. For better understanding of this concept of man's superiority, let's have a glance at a few activities discussed below.

\section{Discussion}

\section{Man, and wildlife resources}

The power of man has been seen where he tames various animals and use them to fetch money. Man has been able to create small ranches and game reserves where they can capture various organisms/animals and use them for their personal gain. Various wildlife has suffered poaching where many species have been killed just for some of their specific parts. Imagine of cases where big animals such as elephants and rhinos are brought down just because of the tusks and ivories. Country like Kenya has lost the white rhino species just because of individuals who do not value these resources. The governments can testify the how the loss of these rare species has affected their economy through tourism sector. The study of our ecosystems and the interaction within the ecosystem justify to us one of the environmental principles of nature that everything was created for a purpose. Elimination of some species in the ecosystem causes ecological imbalance.

Man has also killed various species of wildlife such as antelopes for bush meat. The disturbance caused by man to these resources in their natural habitats interferes with their reproduction. Killing them for bush meat decreases their number and also endangers them [2]. A number of animals and birds have been killed provide bush meat. Still this affects the tourism sector in the country and impacts negatively on the country's economy.

Clearance of vegetation by man has also been seen to impact negatively on the wildlife resources. Vegetation is constantly cleared to pave way for agricultural activities and settlement. Forest ecosystems, wetlands, grassland among other ecosystems 
act as habitat for various wildlife. Clearance or disturbance of these ecosystems make many animals and birds to migrate to other places they deem safer [3]. Clearance of vegetation always make the land to remain bare and susceptible to erosional agents. This allows run-off to flow with a high velocity sweeping the top spoil and degrading land. The top soil swept may also lead to siltation of water bodies making them to lose depth. This direct affect the aquatic organisms.

Encroachment into the wildlife protected areas is another factor where superiority of man has caused a challenge to the wildlife resources. As human population increase, more land is need for settlement and food production (agriculture). People encroach the wildlife reserved areas to undertake various activities. This has always resulted into human-wildlife conflict where man always become the winner. In such cases, many animals are killed and other are scared away and may move to unsafe areas occupied by the predators hence endangering their lives. Encroaching into wildlife reserved areas has reduced these areas and denied many wild animals freedom to move and interact freely within their habitats. They are at times prevented from accessing pasture and water in areas which have been encroached by man. Lack of access to pasture and water interferes with their reproduction.

The population in Kenya has been increasing almost every year and this poses threat on the available natural resource. The major challenge associate with rapid increase in population is that it is associated with poverty and joblessness. The poor individuals and the jobless normally are left with no alternative other than relying basically on what nature provides. They hunt, clear vegetation, burn charcoal, put pressure on available water resources, practice shifting cultivation, make bricks and also take part in washing cars and clothes directly inside river waters affecting the wildlife. Figure 1 shows the Kenyan population growth trend that is so worrying especially on the available natural resources. Job opportunities do not prevail fast as the population grows. At the moment Kenyan population alone is over 47 million. This has put pressure on available natural resources. Nairobi national park is threaten by the constant increase in human population in Nairobi city that needs more space for settlement and other services.

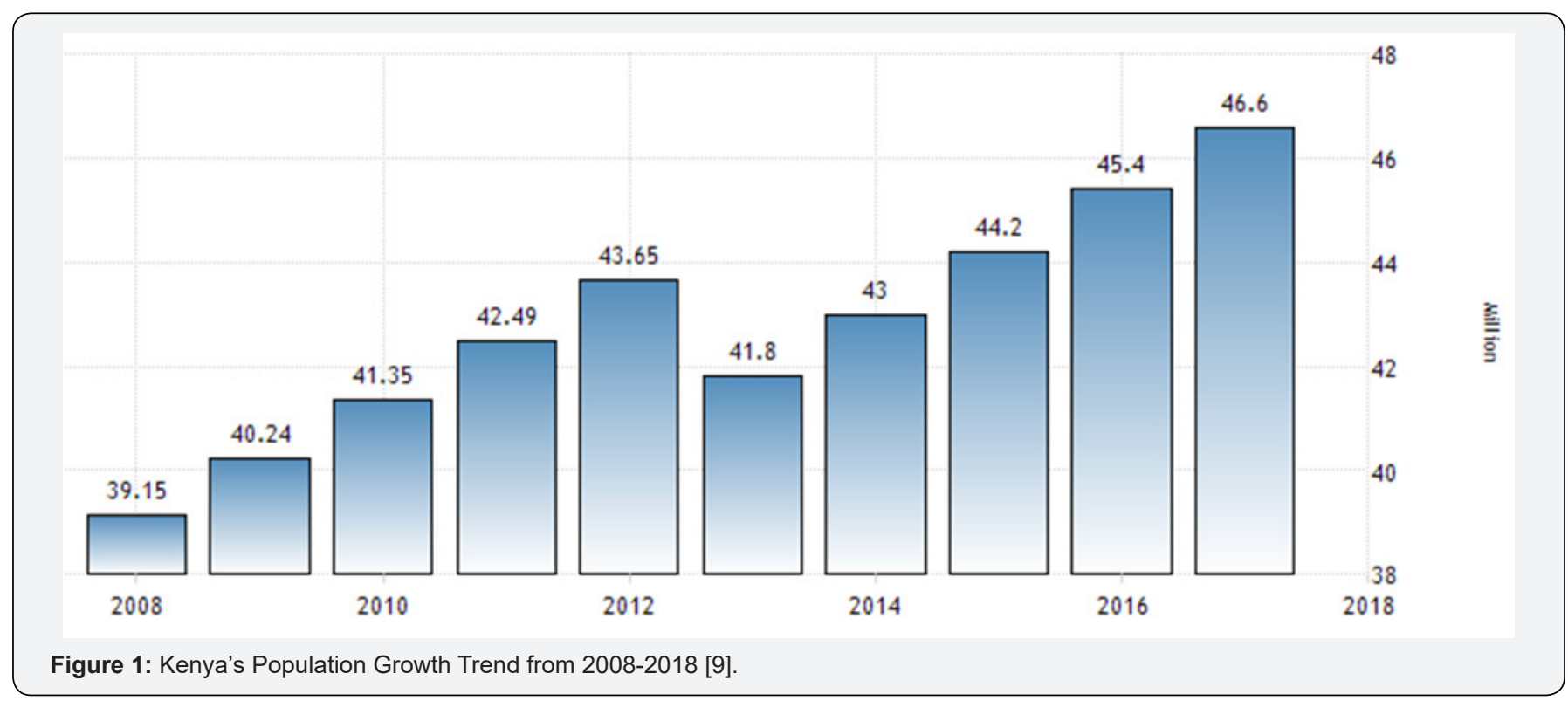

\section{Man and water resources}

Man's power over water resources has been seen in cases where rivers are diverted and even channels changed, dams and other reservoirs are constructed. When a river is diverted, a number of aquatic organisms that used to be supported are subjected to danger of extinction. It might be a problem that may cause death of a wetland supported by that particular river. This would mean that the ecological roles performed by such wetland would be compromised. Water resources have suffered degradation as a result of man's activities. The major activity that has resulted in water resource degradation is deforestation by man. Forests and other forms of vegetation play a major role in creation of micro-climate and contributing to water or hydrological cycle. Depletion of vegetation has direct impact on both water quality and quantity. When vegetation is cleared, the land become prone to soil erosion that leads to siltation of water bodies [4]. In some cases the run-off carries with it nutrients from agricultural lands together with other non-point pollutants such as human feaces from the fields. These cause eutrophication and degradation of water quality. Interference with hydrological cycle may result into aridity and climate change whose impacts are not only seen in human being but other organisms too. It has been noted that the presence of vegetation determines the rainfall pattern in an area.

Many streams and rivers are drying up as a result of deforestation. Mara River in Kenya that empties its water into Lake Natron is a good indicator. Many scholars and conservationists have contended that as result of the degradation of Mau Forest ecosystem, Mara River is faced with death. A number of streams that were supported by Mau forest have also 
dried up. Unfortunately, man assumes the cause of the death of these streams and rivers. Man upholds his superiority thinking that he will continue to live even without these resources. This assumption has also been accompanied by bad politics that is not concerned about the future of man that relies upon sustainable use of natural resources. Poor fishing methods is another factor that has contributed to water quality degradation. Some people have a far as using chemicals for fishing. In their view, they target killing fish but instead of fish alone, the chemicals sprayed on water form layer on water and interfere with dissolved oxygen which is useful for aquatic organisms [5]. These chemicals also lower water quality. Many aquatic organisms are lost as a result of such activities but does man care?

Mining is another factor that has been interfering with water quality and quantity. During this activity, underground water is pumped out to pave way for the miners. This interferes with the water cycles as it is known that underground water is also a contributor in water cycle [6]. The chemicals used in mining such as mercury which is a heavy metal also degrade water quality and this might in turn impact on human health being that human is a consumer of this resources. It is worth noting that all these activities that human being undertake that negatively impact the environment revolve and affect the very survival of man. Where water quality is degraded, man a consumer becomes subjected to water borne diseases. The moment deforestation occur as a result of man's activities such as charcoal burning and agriculture, water cycle is interfered with and rainfall pattern changes. This negatively affects agricultural activities that man relies on. A lot of pollution is also realized as vegetation help in air purification. Pollution of air also affects man. Air pollution may result into climate change which negatively affect man and other organisms. It therefore applies that when we fail to take care of nature, we drink from a cup of poison that we ourselves have made.

\section{Man and forest resources/vegetation}

The earth's vegetation cover has suffered degradation as a result of a number of human activities. Establishment of settlements has led to the loss of land cover. Vast areas have been cleared to provide room for establishment of structure that enables man fins shelter. Agricultural activities have also impacted negatively on vegetation as agriculture normally start with clearance of vegetation. Charcoal burning is another activity that has been identified to contribute immensely to loss of vegetation cover. Similarly, industrialization has become a factor that also contribute to degradation of forests and vegetation cover. The paper milling industries have been sourcing their raw materials from forests. Urbanization has also led to vegetation degradation. As a result of urban sprawl, more land is subjected to vegetation clearance. The land cover is lost to pave way to various urban development activities. The rangeland and riparian zones are being encroached and degraded as a result of urbanization [1].

The most unfortunate thing is that urban population is on constant rise globally. In Kenya for example, most urban centres are characterized by inadequate housing service supply. Table 1 indicates how world urban population has been increasing. This implies that more housing facilities are required together with other infrastructural services. The land cover is lost rapidly as most land is transformed and their uses change. More natural environment are being changed into built environment. This leads to loss of vegetation. The ecological roles performed by vegetation cannot be overstated. They contribute in air purification, completion of hydrological cycle and also take part in assimilation of wastes. Vegetation also provide habitat to various bird species and other forms of biodiversity. Vegetation keeps the compactness of the soil hence controlling soil erosion. As was mentioned earlier provision of natural oxygen could be the most important role performed by vegetation which benefits not only man but other living creature on earth [7]. The natural oxygen is so useful and has been categorized by other scholars as the most important resource of all the resources provided by nature. This is because no living organisms can do without it. Therefore, anything that disrupts supply of oxygen normally disrupts the very survival of all life-forms on or under the earth's surface. Urban sprawl has been a major threat to vegetation since it leads to transformation of land from natural to built environment. The built environment normally compromises the ecological roles performed by the natural resources. The resources become subjected to pressure and new conditions that threaten their existence hence other end up getting extinct [3].

Table 1: The Population of the world from 1955-2018 [10].

\begin{tabular}{|c|c|c|c|c|c|c|c|c|}
\hline Year (July 1) & Population & $\begin{array}{l}\text { Yearly \% } \\
\text { Change }\end{array}$ & Yearly Change & $\begin{array}{c}\text { Median } \\
\text { Age }\end{array}$ & $\begin{array}{l}\text { Fertility } \\
\text { Rate }\end{array}$ & $\begin{array}{c}\text { Density }(\mathrm{P} / \\
\left.\mathrm{Km}^{2}\right)\end{array}$ & $\begin{array}{l}\text { Urban } \\
\text { Pop\% }\end{array}$ & $\begin{array}{c}\text { Urban Popula- } \\
\text { tion }\end{array}$ \\
\hline 2018 & $7,632,819,325$ & $1.09 \%$ & $82,557,224$ & 29.9 & 2.51 & 51 & $54.9 \%$ & $4,186,975,665$ \\
\hline 2017 & $7,550,262,101$ & $1.12 \%$ & $83,297,821$ & 29.9 & 2.51 & 51 & $54.4 \%$ & $4,110,778,369$ \\
\hline 2016 & $7,466,964,280$ & $1.14 \%$ & $83,955,460$ & 29.9 & 2.51 & 50 & $54.0 \%$ & $4,034,193,153$ \\
\hline 2015 & $7,383,008,820$ & $1.19 \%$ & $84,967,932$ & 30 & 2.52 & 50 & $53.6 \%$ & $3,957,285,013$ \\
\hline 2010 & $6,958,169,159$ & $1.24 \%$ & $83,201,955$ & 29 & 2.57 & 47 & $51.3 \%$ & $3,571,272,167$ \\
\hline 2005 & $6,542,159,383$ & $1.26 \%$ & $79,430,479$ & 27 & 2.63 & 44 & $48.9 \%$ & $3,199,013,076$ \\
\hline 2000 & $6,145,006,989$ & $1.33 \%$ & $78,706,515$ & 26 & 2.75 & 41 & $46.5 \%$ & $2,856,131,072$ \\
\hline 1995 & $5,751,474,416$ & $1.53 \%$ & $84,106,191$ & 25 & 3.02 & 39 & $44.7 \%$ & $2,568,062,984$ \\
\hline 1990 & $5,330,943,460$ & $1.81 \%$ & $91,432,333$ & 24 & 3.44 & 36 & $42.9 \%$ & $2,285,030,904$ \\
\hline
\end{tabular}




\section{International Journal of Environmental Sciences \& Natural Resources}

\begin{tabular}{|c|c|c|c|c|c|c|c|c|}
\hline 1985 & $4,873,781,796$ & $1.80 \%$ & $83,074,052$ & 23 & 3.60 & 33 & $41.1 \%$ & $2,003,049,795$ \\
\hline 1980 & $4,458,411,534$ & $1.79 \%$ & $75,864,867$ & 23 & 3.87 & 30 & $39.2 \%$ & $1,749,539,272$ \\
\hline 1975 & $4,079,087,198$ & $1.97 \%$ & $75,701,910$ & 22 & 4.46 & 27 & $37.6 \%$ & $1,534,721,238$ \\
\hline 1970 & $3,700,577,650$ & $2.07 \%$ & $72,196,992$ & 22 & 4.92 & 25 & $36.5 \%$ & $1,350,280,789$ \\
\hline 1965 & $3,339,592,6888$ & $1.94 \%$ & $61,276,032$ & 23 & 4.96 & 22 & N.A. & N.A. \\
\hline 1960 & $3,033,212,527$ & $1.82 \%$ & $52,193,998$ & 23 & 4.89 & 20 & $33.6 \%$ & $1,019,494,911$ \\
\hline 1955 & $2,772,242,535$ & $1.80 \%$ & $47,193,563$ & 23 & 4.96 & 19 & N.A. & N.A. \\
\hline
\end{tabular}

As provided in Table 1, the world's urban population was only 1 billion in the year 1960. In 2018, it has risen to 4.1 billion. Remember that this population need shelter, food and other services. This increase can be calculated in term of pressure and loss or depletion of natural resources. As time continues, the natural vegetation will continue to be degraded and depleted. Vegetation has to pave way for agriculture that feeds this population and at the same time provide room for development of settlements. Remember that the rural population has not been provided in this case. The rural population also grows at that faster rate and if awareness is not created or the rural community is not empower with sustainable environmental management skills, then the land that feeds people will not be productive because vegetation influences climate of a region. Degrading the forests and vegetation directly impacts on the water cycle and the very survival of other resources such as wildlife. The presence of vegetation also contributes in availing nutrient inform of humus to be recycled. This nourishes soil fertility that also translate to better yield in terms of agricultural production. Vegetation also protects the top soil from being eroded. The presence of vegetation reduces run-off velocity, and this enables infiltration which in turn leads to recharge of underground water.

As was previously noted, the tendency of man in belittling other resources has resulted into continuous problems that has endangered these resources and the future generations. There is indiscriminate logging, felling and clearance of vegetation whose role in supporting human life cannot be overemphasized. A few individuals have started appreciating that it is almost impossible to live without vegetation. Vegetation if the mother of oxygen and as an air purifier, it has been seen to contribute immensely in controlling climate change [4]. Some scholars have advocated for greening our economies and urban centers. Our urban centers have been seen to contribute larger percentage of pollutants into the atmosphere. Many industries are found in urban centers and the level of emissions is high. One of the most preferred remedy for pollution problem is greening our urban centers. Vegetation will act as carbon sinks and this reduces level of pollutants in the atmosphere. The only challenge in adopting this mechanism is the human mindset that focused on what benefits him at the moment but not his future. Our superiority over resources has narrowed of concern in undertaking the responsibility that was given to us. The responsibility of being stewards of other resources for our own good.

\section{Man and the Land Resources}

Business community has regarded land as a factor of production. A lot is generated by land for human survival. Land a component of the environment (lithosphere) support various human activities and other form of biodiversity. It is a habitat for various macro-and micro-organisms such as earth-warms that help in soil aeration. Land provides anchorage to plants and/or vegetation whose roles have been discussed above. It in land that nutrient is recycled and taken up by these plants. Plats also taken in soil water from the land itself [2].

Apart from supporting human settlement and agricultural activities, man benefits from land resources such as minerals resources. Land has enabled production and processing of building materials such as stones and bricks. The only concern we have now is that despite having known the benefits that accrue from these resources, human has not taken the initiative to find how these resources can be used sustainably. In most cases, brick making is always undertaken at or near wetland where water can be accessed easily. As a result such activities, the wetlands are degraded and this always led to the loss of biodiversity supported by the wetlands and extinction of some species. The activity of brick making in most cases leaves the land degraded. Man has not taken the initiative of restoring the degraded lands.

Extracting minerals has also led to land degradation. Land dereliction problems have been seen in most areas where mining takes place. A good example is in Macalder gold mines in Nyatike Sub-County, Migori County in Kenya. Poor methods of mining in these areas have resulted into degradation of water quality and quantity [5]. The underground water is pumped out during mining to enable the miners access and extract the minerals. As was noted earlier, some chemicals such as mercury are used in processing of these minerals contains heavy metals that later impact on human health when they get into water systems. The places where mining has been undertaken become hazardous and disastrous due to open pits left at the mining points. Quarrying is another activity that had led to land degradation. This activity starts and involves clearance of vegetation. It makes the land to be ragged and loses its aesthetic value. The above discussed activities have been seen to contribute to the well-being of human but negatively affect the environmental resources upon which the future of human depends. The increase in human population is a major factor that has made it difficult to use the resources sustainably. Natural resource degradation is also influence by 
lack of understanding and appreciation by individuals. Almost everyone knows the contributions of various natural resources in their daily lives but there is an assumption that they can do without the natural resources. This has led to the unsustainable use of these resources.

It has also been noted that land as a resource also suffer rapid increase in human population. Land is fragmented, it is over-cultivated, it loses its cover and it is subjected to agents of erosion which sweeps its nutrients and also make it rugged. Over-cultivation also makes land lose its nutrients/fertility. The consistency in increase in human population has also been seen in many African countries including the Sub-Saharan Africa. Kenya is one of the examples of the countries where human population increase is consistent. As was mentioned earlier, the increase in human population is inversely proportional to natural resources regeneration. The rate at which the natural resources regenerate is much slower than the rate at which the human population increases. As was mentioned earlier, the major driver to natural resources degradation is the increase in human population together with technological advancement. Human population increase creates pressure on the available resources. It is from that increase in human population that overexploitation of these resources occurs. More land cover is lost a result of increased or mechanized agriculture to help provide food for the increased population. More settlements are also required to provide shelter for the increased human population. Agriculture, settlements, mining, overgrazing, urbanization together with industrialization have contributed to loss of land cover.

From Table 2 it is clear that land as a resource will continue to suffer fragmentation based on the constant rise in population projected. Going by the forecast, it has been noted that by 2020 we shall have a world urban population of $4.3 \mathrm{billion}$. This is projected to increase to 6.3 billion by 2050 . Considering the current pressure we have on land together with other natural resources, we can ask ourselves whether the present and future generation will have enough from these natural resources. Going by the current trend of exploitation of natural resources, if we do not take an initiative to advocate for sustainable use of these resources then even our own lives are endangered It has been noted that the world's population is in constant increase. The trend shown in increase in population is an indicator of the increased demand for the available natural resources. The only challenge is that the as population increases, the natural resources are continuing to be depleted. This calls for proper management and sustainable of these resources. The forested areas and rangelands continue to disappear as human transform them to other uses. The built environment increases, land is fragmented, more pressure on available water resources among other challenges realized. Water resources are endangered. The degraded wetlands, forest ecosystems and rangelands are major contributors to the atmospheric moisture recharge hence completion of hydrological cycle.

Table 2: The Forecast of World Population from 2020-2050 [11].

\begin{tabular}{|c|c|c|c|c|c|c|c|c|}
\hline Year (July 1) & Population & $\begin{array}{c}\text { Yearly \% } \\
\text { Change }\end{array}$ & Yearly Change & $\begin{array}{c}\text { Median } \\
\text { Age }\end{array}$ & $\begin{array}{c}\text { Fertility } \\
\text { Rate }\end{array}$ & $\begin{array}{c}\text { Density (P/ } \\
\mathbf{K m}^{2} \text { ) }\end{array}$ & $\begin{array}{c}\text { Urban } \\
\text { Pop\% }\end{array}$ & Urban Population \\
\hline 2020 & $7,795,482,309$ & $1.09 \%$ & $82,494,698$ & 31 & 2.47 & 52 & $55.6 \%$ & $4,338,014,924$ \\
\hline 2025 & $8,185,613,757$ & $0.98 \%$ & $78,026,290$ & 32 & 2.43 & 55 & $57.5 \%$ & $4,705,773,576$ \\
\hline 2030 & $8,551,198,644$ & $0.88 \%$ & $73,116,977$ & 33 & 2.39 & 57 & $59.2 \%$ & $5,058,158,460$ \\
\hline 2035 & $8,892,701,940$ & $0.79 \%$ & $68,300,659$ & 34 & 2.35 & 60 & $60.7 \%$ & $5,394,234,712$ \\
\hline 2040 & $9,210,337,004$ & $0.70 \%$ & $63,527,013$ & 35 & 2.31 & 62 & $62.1 \%$ & $5,715,413,029$ \\
\hline 2045 & $9,504,209,572$ & $0.63 \%$ & $58,774,514$ & 35 & 2.27 & 64 & $63.5 \%$ & $6,030,924,065$ \\
\hline 2050 & $9,771,822,753$ & $0.56 \%$ & $53,522,636$ & 36 & 2.24 & 66 & $64.9 \%$ & $6,338,611,492$ \\
\hline
\end{tabular}

Narrowing down to Kenya, it is evidenced that just like other countries in African continent, the population has been increasing steadily. Table 3 shows the rise in Kenyan population form the year 1950-2018. In 1950, the Kenyan population was only 6 million. There has been steady increase in population and in 2018, the population has reached 50.9 million as per the source indicated. With this, there is no doubt that natural resources in Kenya suffer as a result of this population increase. It is not only land resources that are put under pressure but also water and other resources. As was mentioned earlier, the consequences of Kenyan population increase and man's superiority has been seen well in Mau Forest Complex where people encroach and others go inside the forest to grab land and claim ownership of such lands. The consequence is loss of vegetation and drying up of rivers and streams supported by this ecosystem. These consequences are not only on water resources but also on other biodiversity.

Table 3: The Population of Kenya since 1950-2018.

\begin{tabular}{|c|c|c|c|c|c|c|}
\hline Year & Population\% & Male\% & Female\% & Density $\mathbf{K m}^{2}$ & Population Rank & Growth Rate \\
\hline 2018 & $50,950,879$ & $49.70 \%$ & $50.30 \%$ & 87.79 & 28 & $2.52 \%$ \\
\hline 2017 & $49,699,862$ & $49.70 \%$ & $50.30 \%$ & 85.64 & 28 & $2.56 \%$ \\
\hline 2016 & $48,461,567$ & $49.70 \%$ & $50.30 \%$ & 83.50 & 29 & $2.59 \%$ \\
\hline 2015 & $47,236,259$ & $49.70 \%$ & $50.30 \%$ & 81.39 & 29 & $2.70 \%$ \\
\hline
\end{tabular}




\section{International Journal of Environmental Sciences \& Natural Resources}

\begin{tabular}{|c|c|c|c|c|c|c|}
\hline 2010 & $41,350,152$ & $49.71 \%$ & $50.29 \%$ & 71.25 & 31 & $2.78 \%$ \\
\hline 2005 & $36,048,288$ & $49.68 \%$ & $50.32 \%$ & 62.11 & 33 & $2.77 \%$ \\
\hline 2000 & $31,450,483$ & $49.66 \%$ & $50.34 \%$ & 54.19 & 33 & $2.78 \%$ \\
\hline 1995 & $27,346,456$ & $49.71 \%$ & $50.29 \%$ & 47.12 & 35 & $3.16 \%$ \\
\hline 1990 & $23,402,507$ & $49.78 \%$ & $50.22 \%$ & 40.32 & 37 & $3.56 \%$ \\
\hline 1985 & $19,651,225$ & $49.80 \%$ & $50.20 \%$ & 33.86 & 37 & $3.85 \%$ \\
\hline 1980 & $16,268,990$ & $49.80 \%$ & $50.20 \%$ & 28.03 & 40 & $3.82 \%$ \\
\hline 1975 & $13,486,629$ & $49.81 \%$ & $50.19 \%$ & 23.24 & 45 & $3.69 \%$ \\
\hline 1970 & $11,252,492$ & $49.88 \%$ & $50.12 \%$ & 19.39 & 47 & $3.43 \%$ \\
\hline 1965 & $9,504,703$ & $49.99 \%$ & $16.38 \%$ & 16.38 & 51 & $3.24 \%$ \\
\hline 1960 & $8,105,440$ & $50.15 \%$ & $49.85 \%$ & 13.97 & 55 & $3.04 \%$ \\
\hline 1955 & $6,979,931$ & $50.27 \%$ & $49.73 \%$ & 12.03 & 57 & $2.81 \%$ \\
\hline 1950 & $6,076,758$ & $50.43 \%$ & $49.57 \%$ & 10.47 & 60 & $0.00 \%$ \\
\hline
\end{tabular}

It becomes apparent that with this constant increase of population, our natural resources are endangered. The protected areas that were formally preserved are now target for other development activities and even settlement schemes. A good example is Mau forest Complex in Kenya where some individuals were issued with title deeds to own land not even in the riparian zones of the forest but within the forest. Ironically the people issuing these title deeds are well learned and more informed. They are better placed in terms of the knowledge about consequences of forest degradation. The only thing they focus on is the retention of their political positions but not the well-being of the community. Nairobi national park is also facing encroachment as the urban expands. The city of Nairobi has led to death of Nairobi River that has turned into a sewage. Though the activities to restore the river are underway but the aquatic organisms that were formally supported by the river got extinct.

Table 4 shows the Kenya population projection from the year 2010 to 2095. If you study the trend, it is clear that an increase is realized after every interval of five years. All this translates to pressure on available resources that may lead to their depletion. Several rivers are also endangered especially the ones that flow

through urban areas such River Migori, Sare in Migori County, Kenya and Ewaso Nyiro South that passes through Narok town in Narok County, Kenya. The superiority on man has made him to belittle what these ecosystems offer. They are now turning the natural resources (rivers) into a dump site. Most of the urban wastes are dumped into the rivers. The people down streams that utilize these waters are becoming vulnerable to water borne disease [6]. In urban areas what is considered pure water or the water that is preferred is the piped one. The modern man does not value the natural source of the water but prefer the bottled water. The only question is what is the source of piped and bottled water that we prefer taking? These are some of the misunderstandings and confusion that we need to alienate ourselves from. How can a product be more preferred that the source. The catchment areas are being degraded yet we still need the water down-stream. Many forests are no more and we complain of unreliable rainfall in our regions. Small sized nets are used for fishing and other poor methods such as use of chemicals and we ask ourselves the whereabouts of various fish species that we used to see in the past. When we take time to analyze the changes that we are now experiencing and the ones that have occurred over time, the causes of these changes revolve around us.

Table 4: The Projection of Kenyan Population (2020-1095).

\begin{tabular}{|c|c|c|c|c|c|c|}
\hline Year & Population & \%Male & $\%$ Female & Density $\left(\mathrm{km}^{2}\right)$ & Population Rank & Growth Rate \\
\hline 2020 & $53,491,697$ & $49.70 \%$ & $50.30 \%$ & 92.17 & 27 & $0.00 \%$ \\
\hline 2025 & $60,063,158$ & $49.70 \%$ & $50.30 \%$ & 103.49 & 25 & $2.34 \%$ \\
\hline 2030 & $66,959,993$ & $49.72 \%$ & $50.28 \%$ & 115.38 & 24 & $2.20 \%$ \\
\hline 2035 & $74,086,106$ & $49.73 \%$ & $50.27 \%$ & 127.65 & 21 & $2.04 \%$ \\
\hline 2040 & $81,286,865$ & $49.74 \%$ & $50.26 \%$ & 140.06 & 21 & $1.87 \%$ \\
\hline 2045 & $88,434,154$ & $49.75 \%$ & $50.25 \%$ & 152.38 & 21 & $1.70 \%$ \\
\hline 2050 & $95,467,137$ & $49.75 \%$ & $50.25 \%$ & 164.49 & 20 & $1.54 \%$ \\
\hline 2055 & $102,302,686$ & $49.74 \%$ & $50.26 \%$ & 176.27 & 19 & $1.39 \%$ \\
\hline 2060 & $108,838,578$ & $49.73 \%$ & $50.27 \%$ & 187.53 & 18 & $1.25 \%$ \\
\hline 2065 & $114,980,216$ & $49.70 \%$ & $50.30 \%$ & 198.12 & 18 & $1.10 \%$ \\
\hline 2070 & $120,634,465$ & $49.67 \%$ & $50.33 \%$ & 207.86 & 17 & $0.96 \%$ \\
\hline 2075 & $125,717,353$ & $49.65 \%$ & $50.35 \%$ & 216.62 & 17 & $0.83 \%$ \\
\hline 2080 & $130,208,287$ & $49.62 \%$ & $50.38 \%$ & 224.36 & 18 & $0.70 \%$ \\
\hline
\end{tabular}




\section{International Journal of Environmental Sciences \& Natural Resources}

\begin{tabular}{|l|l|l|l|l|l|l|}
\hline 2085 & $134,106,797$ & $49.59 \%$ & $50.41 \%$ & 231.07 & 19 & $0.59 \%$ \\
\hline 2090 & $137,384,135$ & $49.56 \%$ & $50.40 \%$ & 236.72 & 19 & $0.48 \%$ \\
\hline 2095 & $140,049,179$ & $49.53 \%$ & $50.74 \%$ & 241.31 & 19 & $0.38 \%$ \\
\hline
\end{tabular}

Man has refused to accept that changes in rainfall patterns and loss of various species of organisms are as a result of his own activities. How can we expect a reliable rainfall in a region with totally no vegetation? The elderly people can confess that initially, they were able to predict rain. They could tell months of the year when rainfall was expected and could even start planting. Currently, the traditional methods of weather prediction are challenged [8]. Our technological advancement such as the invention of automobiles including vehicles and industries have filled the atmosphere with fumes and poisonous gases that has caused global warming and acid rains. Burning of fossil fuels has also contributed to this. Unless the modern man realizes where and how he harms that environment, there will be no life. Climate change has led to total loss of biodiversity and extinction of other species which cannot adapt to the new climatic factors [9-12].

\section{Conclusion}

Superiority and pride of man overs natural resource has led to death of many resources. However, there is a calamity that also awaits man as these resources depreciate and continue being depleted. Man causes his own problem by degrading and depleting the natural resources through unsustainable use. Our lives barely depend on these resources and this why they were made available before man was created. For those who are believer in the Bible, man was created on the sixth day after vegetation, water and other creatures had been made available for his use. He was then given power to increase in number fill the earth and subdue it. It imperative to understand that the power that was given to man over the other creatures was to enable him to be a steward. Misinterpretation of this power and upholding our superiority over other natural resources has endangered these resources. They are now diminishing and it is upon them that our lives are

\section{References}

1. Heath J, Binswanger $H$ (2008) Natural resource degradation effects of poverty and population growth are largely policy induced: the case of Colombia.

2. Hof A, Addy L, Rischkowsky B (2003) Degradation of Natural Resources or Necessary Intensification of Land Use to Sustain a Growing Number of Users? The case of the Zamfara Reserve, Northwest Nigeria. Conference on International Agricultural Research for Development.

3. Gogoi L (2013) Degradation of Natural Resources and its Impacts on the Environment. A Study in Guwahati City, Assam, India. International Journal of Scientific and Research Publications 3(12).

4. Katar Singh (2009) Environmental Degradation and Measures for Its Mitigation with Special Reference to India's Agricultural Sector. Indian Journal of Agriculture and Economics 64(1).

5. Mahesh R (2006) Poverty, Inequality and Natural Resource Degradation: An Investigation into the Small-Scale Fishery Sector of South Kerala. A PhD Thesis Submitted to the Cochin University of Science and Technology.

6. Rasul G, Karki M (2013) Political Ecology of Degradation of Forest Common in the Chittagong Hill Tracts of Bangladesh. International Centre for Integrated Mountain Development.

7. Aubell H, Mensah H (2007) Natural Resource Exploitation, Environment and Poverty; Linkages and Impact on Rural Households in Asutifi District in Ghana. Master Thesis in Development Management Faculty of Economics and Social Sciences Agder University College - Spring 2007.

8. Stefano Pagiola (1995) Environmental and Natural Resource Degradation in Intensive Agriculture in Bangladesh. The World Bank, Environmentally Sustainable Development p. 15.

9. https://tradingeconomics.com/kenya/population/

10. http://www.worldometers.info/world-population/

11. http://www.worldometers.info/world-population/

12. http://worldpopulationreview.com/countries/kenya-population/ sustained. Thus using them unsustainably directly translates to committing suicide. Let use embrace proper management and sustainable use of these resources.

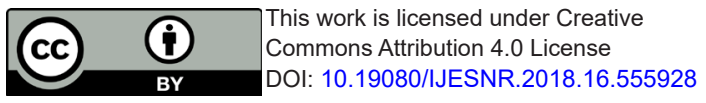

\section{Your next submission with Juniper Publishers will reach you the below assets}

- Quality Editorial service

- Swift Peer Review

- Reprints availability

- E-prints Service

- Manuscript Podcast for convenient understanding

- Global attainment for your research

- Manuscript accessibility in different formats

( Pdf, E-pub, Full Text, Audio)

- Unceasing customer service

Track the below URL for one-step submission https://juniperpublishers.com/online-submission.php 